\title{
NEW DATA ON MARINE RADIOCARBON RESERVOIR EFFECT IN THE EASTERN ADRIATIC BASED ON PRE-BOMB MARINE ORGANISMS FROM THE INTERTIDAL ZONE AND SHALLOW SEA
}

\author{
Sanja Faivre ${ }^{1,2} \cdot$ Tatjana Bakran-Petricioli ${ }^{3}$ Jadranka Barešić ${ }^{4}$ Nada Horvatinčić ${ }^{4}$
}

\begin{abstract}
Radiocarbon analyses of 14 modern, pre-bomb marine organisms collected between AD 1836 and 1946 along the eastern Adriatic coast were performed. The ${ }^{14} \mathrm{C}$ ages of five algal and nine mollusk samples were measured by accelerator mass spectrometry (AMS). Marine ${ }^{14} \mathrm{C}$ reservoir ages $(\mathrm{R})$ and regional offsets $(\Delta \mathrm{R})$ were calculated and compared. The marine reservoir ages of shells and algae significantly differ, even though both inhabit the hard substrate from the intertidal zone to shallow sea. Coralline algae had a considerably lower reservoir age $\left(355 \pm 34{ }^{14} \mathrm{C}\right.$ yr $)$ and $\Delta \mathrm{R}$ value $\left(-9 \pm 34{ }^{14} \mathrm{C}\right.$ yr $)$ than mollusks ( $\mathrm{R} 513 \pm 53{ }^{14} \mathrm{C}$ yr; $\Delta \mathrm{R} 154 \pm 52{ }^{14} \mathrm{C}$ yr), though the variability of $\mathrm{R}$ was high in both groups. Although the microlocations of pre-bomb samples were not known and the studied mollusk species are able to inhabit marine or estuarine environments, it can be assumed that they were not significantly influenced by a freshwater admixture, due to their $\delta^{13} \mathrm{C}$ values being mostly in the marine range. However, as the entire eastern Adriatic is formed in carbonates, mollusk shells could be influenced by limestone-depleted ${ }^{14} \mathrm{C}$. In examining new data together with previously published data, the marine reservoir effect (MRE) for the Adriatic area is estimated to be $424 \pm 57{ }^{14} \mathrm{C}$ yr ( $\triangle \mathrm{R}$ is $77 \pm 57{ }^{14} \mathrm{C} \mathrm{yr}$ ). Without mussel shells, the estimated MRE is $378 \pm 44{ }^{14} \mathrm{C} \mathrm{yr}\left(\triangle \mathrm{R}\right.$ is $\left.28 \pm 45{ }^{14} \mathrm{C} \mathrm{yr}\right)$. The presented values are comparable to the MREs and mean $\Delta$ Rs obtained for the Mediterranean by other authors.
\end{abstract}

\section{INTRODUCTION}

The bimillennium sea-level curves along the eastern Adriatic coast are based on a number of markers. These are primarily archaeological coastal remains (e.g. Vrsalović 1979; Fouache et al. 2000, 2011; Antonioli et al. 2007; Florido et al. 2011), geomorphological markers (e.g. Faivre and Fouache 2003; Benac et al. 2004; Furlani et al. 2011), and sedimentological markers (e.g. Faivre et al. 2011; Marriner et al. 2014). Today, the approach to the study of sea-level variations is multidisciplinary (e.g. Antonioli et al. 2011), and includes the use of a variety of different markers and their combinations where possible.

To obtain greater precision and better accuracy of sea-level curves, the latest research along the eastern Adriatic has been focused on Lithophyllum byssoides algal rims as sea-level markers (Faivre et al. 2010, 2013). Such fossil bioconstructions have proven to be precise sea-level indicators in microtidal environments (Laborel et al. 1994; Morhange 1994). Previous research (Laborel et al. 1994) assumed that Lithophyllum does not appear to be subject to any kind of marine reservoir effect (MRE). This assumption is based on the dating of living thalli. The MRE is particularly important in determining chronological accuracy in temporally short studies, such as the study of 2-kyr relative sea-level variation. This is even more relevant when the data are further compared with archaeological data based on other chronologies, as is often the case in studies of relative sea-level changes.

Currently, the global average marine reservoir age (R) of surface waters is assumed to be around $400{ }^{14} \mathrm{C}$ yr (Stuiver et al. 1986), while recent calibration protocols (Reimer et al. 2013) use a reservoir correction of $405 \pm 22{ }^{14} \mathrm{C}$ yr. However, the marine reservoir effect is variable in time and space. The most common approach to quantify these variations is the determination of $\Delta \mathrm{R}$ values, where the $\Delta \mathrm{R}$ value represents a regional offset from the global average surface water MRE (for which $\Delta \mathrm{R}=0$ ) (Stuiver and Braziunas 1993). Knowledge about the MRE is particularly important in relative sea-level research.

1. University of Zagreb, Faculty of Science, Department of Geography, Marulićev trg 19/II, 10000 Zagreb, Croatia.

2. Corresponding author. Email: sfaivre@geog.pmf.hr.

3. University of Zagreb, Faculty of Science, Department of Biology, Rooseveltov trg 6, 10000 Zagreb, Croatia.

4. Ruđer Bošković Institute, Radiocarbon Laboratory, Bijenička 54, 10000 Zagreb, Croatia.

Proceedings of Radiocarbon and Diet: Aquatic Food Resources and Reservoir Effects First International Conference, 24-26 September 2014, Kiel, Germany

Edited by Ricardo Fernandes, John Meadows, and Alexander Dreves 
The three main methods used to determine the MRE are (a) the use of samples of known age from museum collections, (b) onshore/offshore tephra isochrones, and (c) paired marine/terrestrial samples, i.e. a multiple paired sample approach. An overview of these methods is given in Ascough et al. (2005a). The present study applies radiocarbon dating of marine material with a known calendar date of death of the organism. This approach enables a comparison of contemporaneous atmospheric and marine ${ }^{14} \mathrm{C}$ ages. The deficiency in ${ }^{14} \mathrm{C}$ content of the measured marine sample relative to the global atmospheric calibration curve is then used to calculate the "apparent age" of the material, which allows for the quantification of local deviation from the global R (Ascough et al. 2005a).

Despite significant ongoing research on the temporal and spatial variability of MREs, there are very little data related to the Adriatic Sea. Previous studies of the reservoir effect were performed on four samples of infralittoral organisms from the pre-bomb period along the eastern Adriatic (Siani et al. 2000) and on two pre-bomb samples from the western Adriatic (Langone et al. 1996; Taviani and Correggiari, published in Reimer and McCormac 2002). Mollusk shells were collected from the Venice Lagoon in Italy, from Istria, from the area around Zadar in Croatia, and from the southern Adriatic waters in Montenegro (Figure 1). Langone et al. (1996) collected samples in Rimini, while Taviani and Correggiari (in Reimer and McCormac 2002) collected samples in Barletta. The sample from the Venice Lagoon was excluded from further analyses due to a likely freshwater influence. The reservoir ages of those samples, excluding Venice, varied from 586 to $242{ }^{14} \mathrm{C}$ yr.

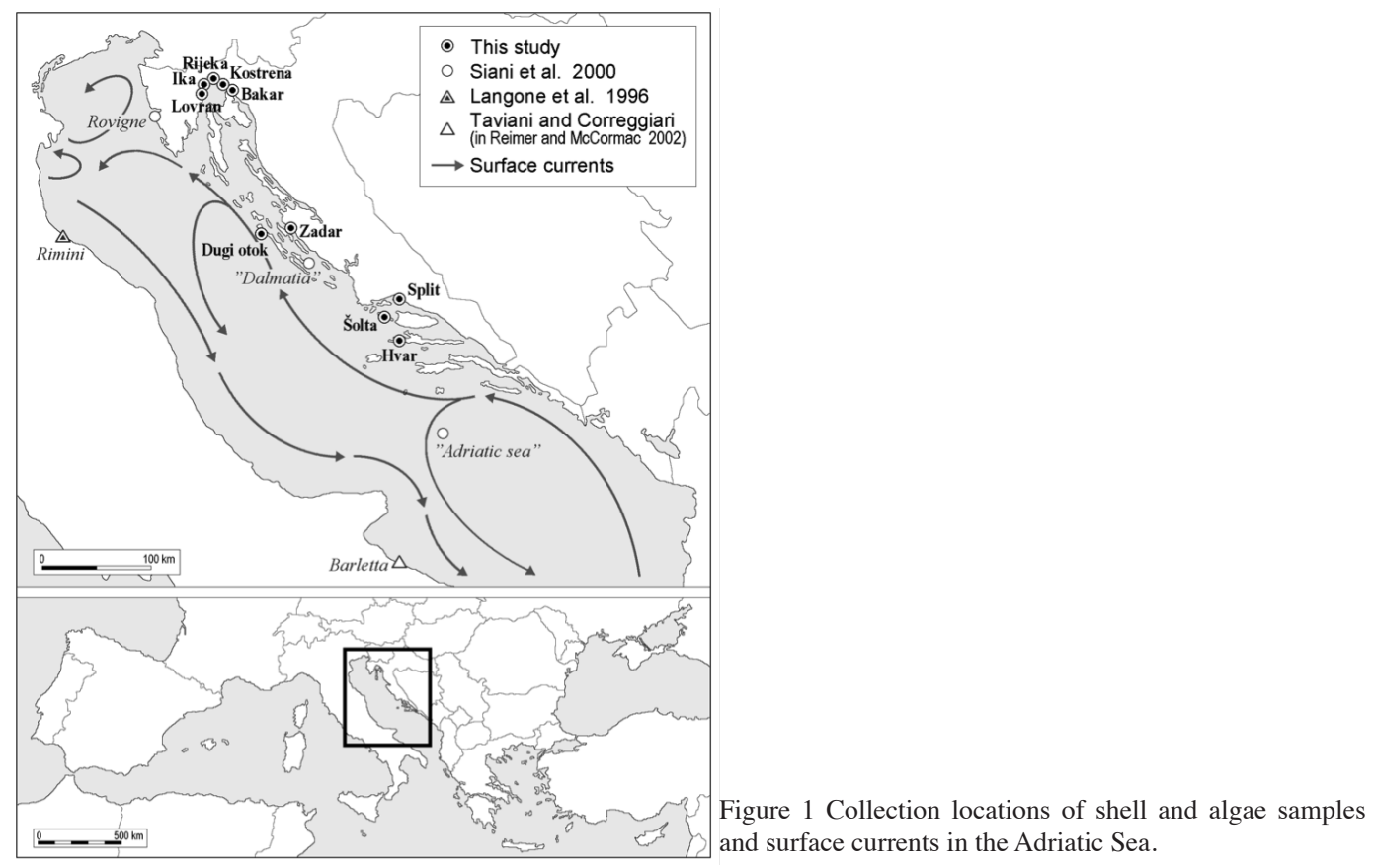

Marine mollusk shells were primarily used to determine the MRE, as there is little knowledge about the reservoir effect of algae. Since no samples of Lithophyllum byssoides from the Adriatic were collected and preserved before AD 1950, we used other algae (Corallina officinalis and Jania rubens) and mollusks that often inhabit algal rims and are found in the intertidal zone and shallow sea (infralittoral zone). This study presents a new pre-bomb data set (14 samples) for the Adriatic Sea, which will be compared with previously published data ( 5 samples) of this region. The objectives of this study are thus to enlarge the database on the marine ${ }^{14} \mathrm{C}$ reservoir effect in the Adriatic 
Sea, which could support the sea-level research, and to ascertain whether there is a difference between the obtained MRE in mollusk shells and algae.

\section{MATERIAL AND METHODS}

The marine organisms for this study were obtained from the collections of the Natural History Museums (NHMs) in Rijeka and Zagreb, the National Museum (NM) in Zadar, and from the Natural History Museum and Zoo (NHMZ) in Split. The mollusks and algae used for ${ }^{14} \mathrm{C}$ dating were collected from AD 1836 to 1946 and represent the pre-bomb period. Table 1 shows the data on the sampled species, and Figure 1 presents the collection sites. For six samples (from Split, Hvar, and Dugi otok), the estimated collection time range is known only; therefore, the mean value of collection time was used. All shells were well preserved, and all bivalves were either articulated or had both shells collected together, suggesting that the collection occurred at the time of death or shortly thereafter.

The samples examined here include algae (three species) and mollusks (five species). All algae species belong to the family Corallinaceae. Both Corallina officinalis (Linnaeus, 1758) and $\mathrm{Ja}$ nia rubens (Linnaeus, J.V. Lamouroux, 1816) have an erect, bushy, articulated thallus, which is attached to the hard substrates (Guiry and Guiry 2015). Corallina officinalis is epilithic, mostly in the lower intertidal and shallow subtidal zone, rarely to $10 \mathrm{~m}$ depth, often forming a dense turf, especially on the exposed coasts. Jania rubens is epilithic or epiphytic on other algae, in the shallow subtidal zone from the sea surface to $20 \mathrm{~m}$ depth. Both algae species are widespread and abundant along the eastern Adriatic coast and can withstand a wide range of ecological conditions, including temperature, salinity, and eutrophication. With regard to their vertical distribution, they inhabit the zone just below Lithophyllum byssoides; Corallina is shallower and closer to L. byssoides, with $J a$ nia found below Corallina. The appearance of the third analyzed alga, an encrusting coralline alga from the Island of Šolta, indicates that it was most likely sampled in a coralligenous community, but as the depth was not recorded, this could not be determined.

Specimens of three species of pre-bomb mytilid bivalves were examined: Mytilus galloprovincialis (Lamarck, 1819), Mytilaster lineatus (Gmelin, 1791), and Mytilaster minimus (Poli, 1795). All three species are very common along the eastern Adriatic. They live attached to the hard substrate by the byssus, mostly in the lower intertidal and shallow subtidal zone up to $3 \mathrm{~m}$ depth. In eutrophic areas such as estuaries or in the northern Adriatic, Mytilus galloprovincialis often forms densely populated belts in the lower intertidal. In areas with abundant temporary freshwater springs (vruljas), as in the Velebit channel, M. galloprovincialis can be found alive to $70 \mathrm{~m}$ depth (Petricioli et al. 1995).

Mytilid bivalves were selected for this research of the MRE as they are common inhabitants of algal rims. Among the excrescences of Lithophyllum byssoides and in turfs of Corallina, especially in the northern Adriatic, abundant populations of small bivalves are often found, mostly juvenile $M$. galloprovincialis, Mytilaster spp., and Lasaea adansoni (Gmelin, 1791). These bivalve species are able to tolerate salinity fluctuations and are capable of inhabiting both marine and estuarine environments.

Two additional mollusk species were sampled. The bivalve Callista chione (Linne, 1758) lives in the sediment, mostly in sand and muddy sand. It is a shallow burrower and it feeds like other bivalves by filtering suspended particles. The contact with the surface of the sediment is maintained by a siphon. The bivalve lives in sediment bottoms in the subtidal zone (from 1 to over $25 \mathrm{~m}$ depth). The gastropod Bolinus brandaris (Linne, 1758) lives on the sediment substrate, mostly on sand and muddy sand in the subtidal zone (from 3 to $50 \mathrm{~m}$ depth, most commonly below $20 \mathrm{~m}$, but has also been reported down to $200 \mathrm{~m}$ ). It is a predator/scavenger. 
Earlier research in the Adriatic Sea (Langone et al. 1996; Siani et al. 2000; Taviani and Correggiari in Reimer and McCormac 2002) was based on three epifaunal bivalve species, Irus irus (Linnaeus, 1758), Mimachlamys varia (Linnaeus, 1758), and Aequipecten opercularis (Linnaeus, 1758), and three infaunal bivalve species, Saccella commutata (Philippi, 1844), Glycymeris glycymeris (Linnaeus, 1758), and Chamelea gallina (Linnaeus, 1758). Table 2 gives the data on these species and Figure 1 presents the collection sites. Scientific names of the animal species used here were updated according to Costello et al. (2008).

Irus irus (Linnaeus, 1758) lives attached to hard substrates, in cavities in limestone, from the shallow subtidal down to $10 \mathrm{~m}$ depth. Saccella commutata (Philippi, 1844) (previously Leda commutata) burrows into fine sediment on the continental shelf and continental margin (depth range of 18-544 m). Glycymeris glycymeris (Linnaeus, 1758) burrows into sediment substrate, mostly sand and muddy sand, in the subtidal zone (around $40 \mathrm{~m}$ of depth). Similarly, Chamelea gallina (Linnaeus, 1758) burrows into sediment, mostly sand and muddy sand, though in the shallow subtidal zone. Mimachlamys varia (Linnaeus, 1758) lives attached to the hard substratum from the shallow subtidal to $80 \mathrm{~m}$ depth. Aequipecten opercularis (Linnaeus, 1758) lives freely, as an active swimmer in the adult phase, on firm sandy to gravely bottoms, down to $180 \mathrm{~m}$ depth.

In researching MRE, it is very important to emphasize that $>90 \%$ of the eastern Adriatic coast is formed in carbonates, while $\sim 6 \%$ is formed in Eocene flysch (Pikelj and Juračić 2013). The main units are Cretaceous carbonates deposited on the Adriatic-Dinaridic carbonate platform (Vlahović et al. 2005), overlain by Paleogene carbonates and siliciclastic sediments (flysch) deposited within foreland basins.

The Adriatic Sea has an elongated shape from SE to NW and an almost landlocked position, which plays an important role in controlling the dynamics of its waters (Figure 1). The basin may be divided into three parts, increasing in depth to the Otranto Strait at its southern entrance (Orlić et al. 1992). The system of surface currents in the Adriatic Sea is the result of the distribution of its thermohaline properties. Along the eastern coast of the Adriatic, an input of the NW current transports salty Levantine water into the Adriatic, while along the west coast, there is an outflow of less saline water from the northern Adriatic. Gradient currents are the main cause of the general cyclonic circulation. The input current is more pronounced in winter along the eastern side and the outflow current in the summer along the western coast of the Adriatic.

Samples were prepared in the Radiocarbon Laboratory at Ruđer Bošković Institute in Zagreb (lab code Z-). The relative specific activity of ${ }^{14} \mathrm{C}\left({ }^{14} \mathrm{a}\right)$ of the carbonate fraction was determined for all samples, while the ${ }^{14} \mathrm{a}$ of the organic fraction was measured in only two samples (algae Corallina officinalis and Jania rubens) due to the very low amount of organic carbon in the samples. For algae and shell samples, approximately $40 \mathrm{mg}$ of sample were hydrolyzed with $4 \% \mathrm{HCl}$ to obtain the $\mathrm{CO}_{2}$. Shell samples were etched in $1 \% \mathrm{HCl}$ prior to hydrolysis in order to remove the surface layer. The organic fraction of two algae (Corallina officinalis and Jania rubens) remaining after hydrolysis were rinsed thoroughly with ultrapure water, dried, and transferred to a precombusted quartz tube together with $\mathrm{Ag}$ and $\mathrm{CuO}$, sealed under vacuum, and finally combusted to obtain the $\mathrm{CO}_{2}$. The obtained $\mathrm{CO}_{2}$ was converted to graphite $\left(1.5 \mathrm{mg}\right.$ target) for $\mathrm{AMS}{ }^{14} \mathrm{C}$ measurement by using zinc reduction (Krajcar-Bronić et al. 2010; Sironić et al. 2013). An aliquot of $\mathrm{CO}_{2}$ from each sample was sealed in a glass tube before graphitization in order to determine the $\delta^{13} \mathrm{C}$ value. The ${ }^{14} \mathrm{a}$ of the graphite target was measured with a $500 \mathrm{kV}$ compact Pelletron AMS unit at the Center for Applied Isotopes Studies, University of Georgia, USA (Cherkinsky et al. 2010). The $\delta^{13} \mathrm{C}$ values were determined with an isotope ratio mass spectrometer (IRMS) at the same institute. The ${ }^{14} \mathrm{C}$ ages 
were corrected for isotope fractionation using the $\delta^{13} \mathrm{C}$ values measured by IRMS and normalized to $-25 \%$ VPDB (Stuiver and Polach 1977).

Reservoir ages were calculated as the difference between the measured ${ }^{14} \mathrm{C}$ age (BP) and the BP age for the year of sample collection obtained from the IntCal13 (Reimer et al. 2013) curve. $\Delta \mathrm{R}$ values were calculated in the same manner but using the marine calibration curve as outlined in Stuiver et al. (1986), Stuiver and Braziunas (1993), and Rusell et al. (2011). All calculations were performed using the OxCal software v 4.2 (Bronk Ramsey 2009a,b; Bronk Ramsey and Lee 2013) and the latest calibration curves: IntCal13 (NH for our samples) and Marine13 (Reimer et al. 2013), respectively. Calculations were made separately for shells and algae. All samples within the group were considered as a single phase (Bronk Ramsey 2009a). Algorithms of similar calculations are described in Macario et al. (2015) and Facorellis and Vardala-Theodoru (2015). The consistency of the obtained results was checked by the "RScaled" outlier model (for $95 \%$ significance) within OxCal, as recommended by Bronk Ramsey (2009b).

The weighted mean of $\Delta \mathrm{R}$ and reservoir ages, as well as empirical standard deviations, i.e. the square root of variance, were calculated for pre-bomb museum samples according to procedures described in the Marine Reservoir Correction Database (Bevington 1969; Ward and Wilson 1978; Stuiver et al. 2015), kept by the 14CHRONO Centre, Queen's University Belfast. Weighted means for pre-bomb samples (Siani et al. 2000; Reimer and McCormac 2002) were updated according to the Marine Reservoir Correction Database and recalculated with CALIB 7.1 software (Stuiver et al. 2015). The ${ }^{14} \mathrm{C}$ ages and $\delta^{13} \mathrm{C}$ values of the organic fraction of two algae species (Jania rubens $\mathrm{Z}-5459,{ }^{14} \mathrm{C}$ age $\mathrm{BP}=27 \pm 23 ; \delta^{13} \mathrm{C}=-22.3 \%$; and Corallina officinalis Z-5454, ${ }^{14} \mathrm{C}$ age $\mathrm{BP}=543 \pm$ $24 ; \delta^{13} \mathrm{C}=-20.0 \%$ ) are not further discussed nor used in the MRE calculation as the two samples are insufficient to discuss the relevance of the organic fraction.

\section{RESULTS AND DISCUSSION}

${ }^{14} \mathrm{C}$ ages, reservoir ages $(\mathrm{R})$, and reservoir offsets $(\Delta \mathrm{R})$ of pre-AD 1950 live-collected marine specimens of known historical age are presented in Table 1. They show a large span of ${ }^{14} \mathrm{C}$ ages for the carbonate fraction (from $159 \pm 21$ to $992 \pm 20 \mathrm{BP}$ ) and reservoir ages (from $51 \pm 26$ to $879 \pm$ $44{ }^{14} \mathrm{C}$ yr). Two samples (Callista chione, Z-5405 and Bolinus brandaris, Z-5406) yielded modern values with a ${ }^{14} \mathrm{C}$ activity of $100.9 \pm 0.3$ and $110.1 \pm 0.3 \mathrm{pMC}$, respectively. However, this may have been due to an archiving error, and the samples were therefore omitted from further MRE analysis.

The large range of ${ }^{14} \mathrm{C}$ and reservoirs ages obtained prompted us to examine their statistical significance. Therefore, two samples of the data set were considered as outliers within the $95 \%$ significance level ("RScaled" function) and thus omitted from further calculations of the weighted means: Jania rubens (Z-5555) from Zadar and Mytilaster minimus (Z-5560) from the Split area (Table 1).

The obtained $\delta^{13} \mathrm{C}$ data of the carbonate fraction of algae and shell samples varied from -5.0 to $0.8 \%$. The average $\delta^{13} \mathrm{C}$ values for algae $(-2.1 \%$ ) were lower than those of mollusk shells $(-0.6 \%$ ) (Table 1). Generally, our data showed lower $\delta^{13} \mathrm{C}$ values compared to those from the Mediterranean and Aegean Seas (-1.3 to $+2.4 \%$, average 1.0\%; Reimer and McCormac 2002). All mollusk shells sampled from the coast of Israel from the pre-bomb period had also higher $\delta^{13} \mathrm{C}$ values between +0.9 and $+2.2 \%$, with a mean value of $1.7 \%$ (Boaretto et al. 2010).

The lower values in the Adriatic could be linked to the influence of freshwater. The Adriatic Sea is a dilution basin, i.e. precipitation and land inflows exceed the loss by evaporation. Generally, the surface salinity decreases from the open southeastern part of the Adriatic Sea towards its northwestern part. The salinity is lower and more variable in coastal zones, and in the northern Adriatic due 
to the influence of the River Po (Gačić et al. 2001). Consequently, the influence of freshwater may be more pronounced in the northern Adriatic. However, no significant regional differences in $\delta^{13} \mathrm{C}$ values were observed in our results (Table 1), thus suggesting these values could be more influenced by local freshwater input. This is supported by the study of Kanduč et al. (2006), which showed that $\delta^{13} \mathrm{C}_{\text {calcite }}$ in Mytilus galloprovincialis shell layers from the eastern Adriatic coast were a reliable indicator of local freshwater influence.

Table 1 Radiocarbon ages, reservoir ages $(\mathrm{R})$, and reservoir offsets $(\Delta \mathrm{R})$ of pre-bomb algae and mollusk samples with collection locations and years. All samples were obtained from the collections of Croatian museums: NHMR - Natural History Museum in Rijeka (6 samples); NHMZ - Natural History Museum in Zagreb (4 samples); NMZ - National Museum in Zadar (1 sample); and NHMZS - Natural History Museum and Zoo in Split (4 samples).

\begin{tabular}{|c|c|c|c|c|c|c|c|c|c|}
\hline $\begin{array}{l}\text { Lab } \\
\text { ID } \\
(Z-) \\
\end{array}$ & $\begin{array}{l}\text { Organ- } \\
\text { ism }\end{array}$ & Species & Location & $\begin{array}{l}\text { Year } \\
\text { collected } \\
\text { (average) }\end{array}$ & $\begin{array}{l}\text { Source } \\
\text { museum }\end{array}$ & $\begin{array}{l}\delta^{13} \mathrm{C} \\
(\%) \\
\text { VPDB }\end{array}$ & $\begin{array}{l}{ }^{14} \mathrm{C} \text { age } \\
\text { (BP) }\end{array}$ & $\begin{array}{l}\mathrm{R} \\
\left({ }^{14} \mathrm{C} \text { yr }\right)\end{array}$ & $\begin{array}{l}\Delta \mathrm{R} \\
\left({ }^{14} \mathrm{C} \text { yr }\right)\end{array}$ \\
\hline 5408 & alga & Jania rubens & Lovran & 1882 & NHMR & -2.8 & $564 \pm 21$ & $451 \pm 32$ & $86 \pm 40$ \\
\hline 5555 & alga & J. rubens & Zadar area & 1836 & NMZ & -0.8 & $159 \pm 21$ & $51 \pm 26$ & $-316 \pm 37$ \\
\hline 5407 & alga & $\begin{array}{l}\text { Corallina offici- } \\
\text { nalis }\end{array}$ & Ika & 1881 & NHMR & -4.1 & $614 \pm 20$ & $501 \pm 33$ & $136 \pm 40$ \\
\hline 5556 & alga & C. officinalis & Split & 1848 & NHMZS & -2.4 & $431 \pm 21$ & $318 \pm 32$ & $-47 \pm 40$ \\
\hline 5557 & alga & $\begin{array}{l}\text { Corallinaceae } \\
\text { indet. }\end{array}$ & Šolta & 1925 & NHMZS & -0.3 & $409 \pm 21$ & $297 \pm 32$ & $-69 \pm 41$ \\
\hline 5560 & bivalve & $\begin{array}{l}\text { Mytilaster min- } \\
\text { imus }\end{array}$ & Split & $\begin{array}{l}1840-1860 \\
(1850)\end{array}$ & NHMZ & -0.6 & $992 \pm 20$ & $879 \pm 44$ & $520 \pm 47$ \\
\hline 5561 & bivalve & M. minimus & Hvar & $\begin{array}{l}1840-1860 \\
(1850)\end{array}$ & NHMZ & 0.2 & $639 \pm 20$ & $518 \pm 41$ & $161 \pm 40$ \\
\hline 5559 & bivalve & Mytilaster lineatus & Dugi otok & $\begin{array}{l}1905-1917 \\
(1910)\end{array}$ & NHMZS & 0.8 & $440 \pm 21$ & $319 \pm 43$ & $-38 \pm 40$ \\
\hline 5562 & bivalve & $\begin{array}{l}\text { Mytilus gallopro- } \\
\text { vincialis }\end{array}$ & Hvar & $\begin{array}{l}1840-1860 \\
(1850)\end{array}$ & NHMZ & -0.8 & $721 \pm 21$ & $600 \pm 41$ & $243 \pm 41$ \\
\hline 5563 & bivalve & $\begin{array}{l}\text { M. galloprovin- } \\
\text { cialis }\end{array}$ & Hvar & $\begin{array}{l}1840-1860 \\
(1850)\end{array}$ & NHMZ & -0.6 & $749 \pm 21$ & $628 \pm 41$ & $271 \pm 41$ \\
\hline 5558 & bivalve & $\begin{array}{l}\text { M. galloprovin- } \\
\text { cialis }\end{array}$ & Dugi otok & $\begin{array}{l}1905-1917 \\
(1910)\end{array}$ & NHMZS & -2.8 & $678 \pm 20$ & $556 \pm 41$ & $200 \pm 41$ \\
\hline 5404 & bivalve & $\begin{array}{l}\text { M. galloprovin- } \\
\text { cialis }\end{array}$ & Bakar & 1917 & NHMR & -0.7 & $578 \pm 20$ & $456 \pm 46$ & $100 \pm 40$ \\
\hline $5405 *$ & bivalve & Callista chione & Kostrena & 1946 & NHMR & -0.3 & $\begin{array}{l}100.9 \pm \\
0.3 \\
(\mathrm{pMC})\end{array}$ & - & - \\
\hline $5406 *$ & $\begin{array}{l}\text { gastro- } \\
\text { pod }\end{array}$ & Bolinus brandaris & Rijeka & 1946 & NHMR & -5.0 & $\begin{array}{l}110.1 \pm \\
0.3 \\
(\mathrm{pMC})\end{array}$ & - & - \\
\hline
\end{tabular}

*For modern samples, the relative specific activity of ${ }^{14} \mathrm{C}$ is given in percent modern carbon (pMC).

The majority of our carbonate samples (nine samples, Table 1) exhibited a $\delta^{13} \mathrm{C}$ ratio within the typical range for marine carbonates: -1 to $2 \%$. Three samples match the extended range ( -4 to $4 \%$ ). However, two samples fell out of the extended range, showing a possible influence of other carbonate sources such as soil $(-5.0 \pm 2 \%$ ) or freshwater $(-9.0 \pm 2 \%$ ) (ranges according to Stuiver and Polach 1977). These were Bolinus brandaris with $\delta^{13} \mathrm{C}-5 \%$ (which was omitted from further consideration as it yielded modern values of $\left.{ }^{14} a\right)$ and Corallina officinalis $\left(\delta^{13} \mathrm{C}-4.1 \%\right.$ ) from Ika Bay (Z-5407). Ika is known for its large submarine freshwater sources (vruljas). Therefore, this sample could have been influenced by freshwater DIC, which may be reflected in the higher MRE, 
and therefore, they were not used in further calculations. Taking into account the aforementioned arguments, we selected three algae samples and six mollusk shell samples in order to compare their MRE.

Table 2 Previously reported ${ }^{14} \mathrm{C}$ ages, $\mathrm{R}$, and $\Delta \mathrm{R}$ values for bivalve shells from the Adriatic Sea.

\begin{tabular}{|c|c|c|c|c|c|c|c|}
\hline $\begin{array}{l}\text { Lab } \\
\text { code }\end{array}$ & Species & $\begin{array}{l}\text { Collection } \\
\text { site }\end{array}$ & $\begin{array}{l}\text { Collection } \\
\text { year }\end{array}$ & $\begin{array}{l}{ }^{14} \mathrm{C} \text { age } \\
\text { (BP) }\end{array}$ & $\begin{array}{l}\mathrm{R} \\
\left({ }^{14} \mathrm{C} \mathrm{yr}\right)\end{array}$ & $\begin{array}{l}\Delta \mathrm{R} \\
\left({ }^{14} \mathrm{C} \mathrm{yr}\right)\end{array}$ & References \\
\hline $\begin{array}{l}\text { GifA- } \\
96718\end{array}$ & $\begin{array}{l}\text { Saccella commutata } \\
\text { (Leda commutate) }\end{array}$ & Rovinj & 1926 & $390 \pm 50$ & $254 \pm 50$ & $-61 \pm 50$ & Siani et al. 2000 \\
\hline $\begin{array}{l}\text { GifA- } \\
96707\end{array}$ & Irus irus & Dalmatia & 1873 & $380 \pm 35$ & $262 \pm 36$ & $-95 \pm 35$ & Siani et al. 2000 \\
\hline $\begin{array}{l}\text { GifA- } \\
96722\end{array}$ & $\begin{array}{l}\text { Glyciymeris glyci- } \\
\text { merys }\end{array}$ & $\begin{array}{l}\text { Adriatic } \\
\text { Sea }\end{array}$ & 1867 & $540 \pm 30$ & $421 \pm 31$ & $61 \pm 30$ & Siani et al. 2000 \\
\hline $\begin{array}{l}\text { CAMS- } \\
12144\end{array}$ & $\begin{array}{l}\text { Aequipecten oper- } \\
\text { cularis }\end{array}$ & $\begin{array}{l}\text { Rimini, } \\
\text { Italy }\end{array}$ & 1911 & $587 \pm 28$ & $487 \pm 29$ & $139 \pm 28$ & Langone et al. 1996 \\
\hline $\begin{array}{l}\text { CAMS- } \\
16299\end{array}$ & $\begin{array}{l}\text { Mimachlamys varia } \\
\text { (Chlamys varia) }\end{array}$ & $\begin{array}{l}\text { Barletta, } \\
\text { Italy }\end{array}$ & 1906 & $570 \pm 60$ & $483 \pm 60$ & $121 \pm 60$ & $\begin{array}{l}\text { Taviani and Correg } \\
\text { giari, in Reimer and } \\
\text { McCormac } 2002\end{array}$ \\
\hline
\end{tabular}

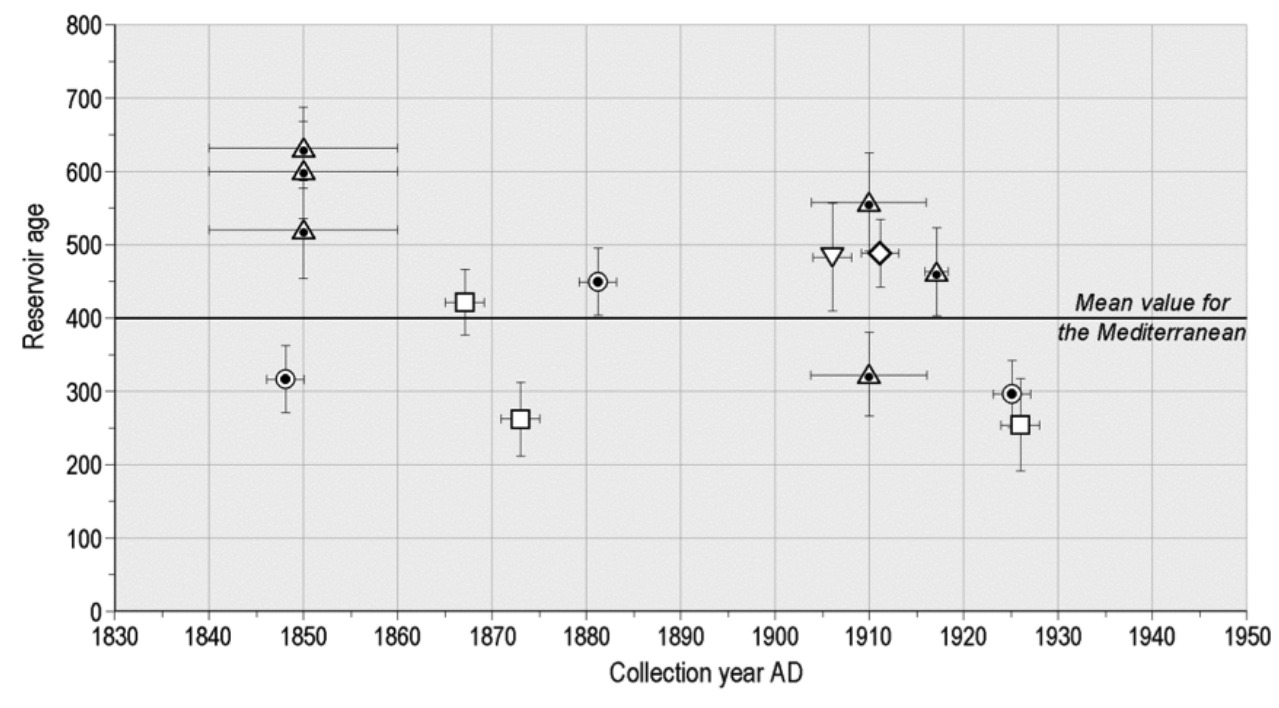
○ Algae, this study
$\triangle$ Shells, this study
$\square$ Shells, Siani et al. 2000

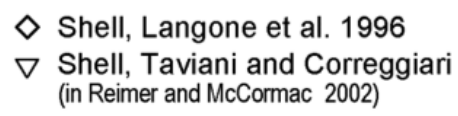

Figure 2 Reservoir age $\mathrm{R}$ as a function of the collection year for samples from the Adriatic Sea. The solid line represents the mean value of the Mediterranean (from Reimer and McCormac 2002).

To date, carbonate mollusk shells (calcite and/or aragonite) have almost exclusively been used for dating. As bivalves are sedentary organisms, in theory they should reflect the local seawater ${ }^{14} \mathrm{C}$ content. They build their shells using carbon from two sources: the external dissolved inorganic carbon (DIC) (mainly bicarbonate) in the seawater and metabolic carbon. The ratio between the two 
sources likely depends on the species and the physiological state of any given organism (Wheeler 1992). However, some bivalves also uptake carbon from particulate food or sediment pore water (Mangerud et al. 2006). Coastal waters often contain some carbon of continental origin.

Algae are primary producers, deriving their carbon for photosynthesis directly from DIC in the seawater. The variation in carbonate $\delta^{13} \mathrm{C}$ values in algae is produced by the relative contribution of carbon used for carbonate precipitation from ambient marine DIC, photosynthesis-modified fluids, and respiration-modified fluids (Lee and Carpenter 2001). On the other hand, the studied mussels are suspension feeders, feeding on fine food particles suspended in the water column. The incorporation of respired ${ }^{13} \mathrm{C}$-depleted carbon into skeleton might affect its $\delta^{13} \mathrm{C}$ record. Typically, less than $10 \%$ of the carbon in the skeleton of Mytilus edulis is of metabolic origin, although higher ratios have been reported for other species, e.g. up to 37\% in marine aragonitic bivalve shells (Gillikin et al. 2007). Consequently, the contribution of metabolic carbon could also account for the lower $\delta^{13} \mathrm{C}$ values.

Gillikin et al. (2006) showed that mussels have a highly selective feeding habit as a primary consumer, assimilating most of their carbon from phytoplankton from the total particulate organic carbon (POC) pool. Phytoplankton is a primary producer in the marine environment. Thus, it derives its carbon from the DIC, like benthic algae. Consequently, we expected that both algae and mussels have a ${ }^{14} \mathrm{a}$ approaching the ocean DIC value and that the MRE of both are similar as algae are primary producers and mussels are primary consumers, but we obtained different results.

Despite high interspecies variation, all mollusk shells (six samples) showed a higher average MRE $\left(513 \pm 53{ }^{14} \mathrm{C}\right.$ yr) than algae (three samples) $\left(355 \pm 34{ }^{14} \mathrm{C}\right.$ yr). The observed interspecies variation in the marine mollusk shell ${ }^{14} \mathrm{C}$ content could be the result of specific feeding strategies in areas where different food resources with nonuniform ${ }^{14} \mathrm{C}$ contents are available, e.g. in regions of carbonate rocks where ${ }^{14} \mathrm{C}$ offsets are observed between grazing and pelagic feeders (Ascough et al. 2009). However, the mollusk samples in this study represent only suspension feeders. Overall, the nine samples had a mean reservoir age of $441 \pm 60{ }^{14} \mathrm{C}$ yr $(\Delta \mathrm{R}=99 \pm 60 \mathrm{yr})$ (Table 3$)$.

Furthermore, the standard deviations (empirical standard deviation) of our data were fairly large, similar to most of the Mediterranean, with the exception of the Tyrrhenian Sea (Reimer and McCormac 2002). Standard deviations were large in both of our data groups, i.e. $84 \mathrm{yr}$ for algae (three samples) and $156 \mathrm{yr}$ for shells (six samples). When both groups were considered, the standard deviation was $163 \mathrm{yr}$ (Table 3). High values of standard deviations, larger than measurement uncertainties, are related to the decadal $\mathrm{R}$ changes, i.e. a decrease of the apparent marine ages of about $220 \mathrm{yr}$ from AD 1900 to 1930 in the Adriatic and the Mediterranean Sea, as previously shown by Siani et al. (2000). However, this could be also related to local variations in the ${ }^{14} \mathrm{C}$ content of seawater.

Due to the large MRE $\left(513 \pm 53{ }^{14} \mathrm{C}\right.$ yr $)$ and $\Delta \mathrm{R}\left(154 \pm 52{ }^{14} \mathrm{C}\right.$ yr $)$, the mussel shells could also be considered separately (Table 3 ) as they strongly influenced the mean values. A similar case was also observed in the Aegean Sea. Reimer and McCormac (2002) showed that Mytilus edulis from the Aegean Sea (Izmir, Turkey) had a larger reservoir age than the average $\left(\mathrm{R}-652{ }^{14} \mathrm{C} \mathrm{yr}\right)$. On the other hand, Ascough et al. (2005b) found that Mytilus edulis from the archaeological site Hornish Point, on the west coast of South Uist, Scotland, far from significant sources of freshwater or carbonate rocks, did not differ in MRE from other studied mollusk species. Consequently, the high MRE and $\Delta \mathrm{R}$ values of shells in our study might be related to the influence of old carbonates on which the entire region is formed.

In pooling the available samples (14 in total) for the Adriatic Sea, the MRE was estimated to be $424 \pm 57{ }^{14} \mathrm{C}$ yr and $\Delta \mathrm{R}$ to be $77 \pm 57{ }^{14} \mathrm{C}$ yr. When mussel shells are excluded, the MRE decreases to 
$378 \pm 44{ }^{14} \mathrm{C}$ yr and $\Delta \mathrm{R}$ to $28 \pm 45{ }^{14} \mathrm{C}$ yr. In both cases, our results are comparable to the mean $\Delta \mathrm{R}$ for the Mediterranean of $58 \pm 15{ }^{14} \mathrm{C}$ yr (Reimer and McCormac 2002) (Table 3) and to the mean $\Delta \mathrm{R}$ $\left(35 \pm 70{ }^{14} \mathrm{C}\right.$ yr) previously reported by Siani et al. (2000), which is predominately based on western Mediterranean measurements. This is in accordance with the conclusion of Reimer and McCormac (2002) that differences in the mean $\Delta \mathrm{R}$ values between the Mediterranean regions are small, with the possible exception of the Aegean Sea.

Table 3 Reservoir ages $\mathrm{R}$ and weighted mean $\Delta \mathrm{R}$ values for Adriatic and Mediterranean samples.

\begin{tabular}{|c|c|c|c|c|c|}
\hline Region & $\begin{array}{l}\text { Mean } \Delta \mathrm{R} \\
\left({ }^{14} \mathrm{C} \text { yr }\right)\end{array}$ & $\begin{array}{l}\mathrm{Nr} \text { of } \\
\text { samples }\end{array}$ & $\begin{array}{l}\text { Empirical } \\
\text { s.d. (yr) }\end{array}$ & $\begin{array}{l}\mathrm{R} \\
\left({ }^{14} \mathrm{C} \text { yr }\right)\end{array}$ & References \\
\hline All Mediterranean & $58 \pm 15$ & 34 & 85 & $400 \pm 16$ & Reimer and McCormac 2002 \\
\hline $\begin{array}{l}\text { All Mediterranean } \\
\text { except the Aegean Sea }\end{array}$ & $45 \pm 14$ & 30 & 75 & $390 \pm 15$ & Reimer and McCormac 2002 \\
\hline Adriatic Sea & $46 \pm 48$ & 5 & 108 & $396 \pm 61$ & Reimer and McCormac 2002 \\
\hline Eastern Adriatic algae & $-9 \pm 34$ & 3 & 84 & $355 \pm 34$ & This study \\
\hline Eastern Adriatic shells & $154 \pm 52$ & 6 & 156 & $513 \pm 53$ & This study \\
\hline $\begin{array}{l}\text { Eastern Adriatic algae } \\
\text { and shells }\end{array}$ & $99 \pm 60$ & 9 & 163 & $441 \pm 60$ & This study \\
\hline All Eastern Adriatic & $66 \pm 60$ & 12 & 157 & $414 \pm 60$ & This study; Siani et al. 2000 \\
\hline $\begin{array}{l}\text { Eastern Adriatic with- } \\
\text { out mussel shells }\end{array}$ & $-12 \pm 36$ & 6 & 78 & $348 \pm 37$ & This study; Siani et al. 2000 \\
\hline $\begin{array}{l}\text { All Adriatic without } \\
\text { mussel shells }\end{array}$ & $28 \pm 45$ & 8 & 96 & $378 \pm 44$ & $\begin{array}{l}\text { This study; Langone et al. 1996; Siani } \\
\text { et al. 2000; Taviani and Correggiari, } \\
\text { in Reimer and McCormac } 2002\end{array}$ \\
\hline All Adriatic & $77 \pm 57$ & 14 & 144 & $424 \pm 57$ & $\begin{array}{l}\text { This study; Langone et al. 1996; Siani } \\
\text { et al. 2000; Taviani and Correggiari, } \\
\text { in Reimer and McCormac } 2002\end{array}$ \\
\hline
\end{tabular}

The reservoir age distribution in the Adriatic Sea showed no particular spatial distribution, though it did show consistent changes over time. The relationship between reservoir age and collection year of marine species is displayed in Figure 2. Siani et al. (2000) noted that the apparent marine ages in the Mediterranean Sea decreased by about $220 \mathrm{yr}$ during the interval AD 1900 to 1930 . Our data, as well as the eastern Mediterranean and Aegean data (Reimer and McCormac 2002), support a similar decline (215 yr) in R ages during this interval.

This study also emphasizes the importance of carefully inventoried and archived museum collections for contemporary scientific research. Such collections can provide valuable data, not only for their originally intended purpose (for botanical and zoological research), but also for research that could not be predicted at the time of collection, in this case, determining the ${ }^{14} \mathrm{C}$ reservoir effect.

\section{CONCLUSIONS}

Marine reservoir ages $(\mathrm{R})$ of the examined pre-bomb shells and algae from the Adriatic Sea significantly differ, despite the fact that both shells and algae inhabit the hard substrate and the intertidal zone to shallow sea, and that they both use carbon from the seawater DIC: algae as primary producers and mollusks (mussels) as selective primary consumers. However, mussels can also form carbonates from metabolic sources, typically up to $10 \%$. Although mussels can often inhabit estuarine environments, our samples (6/7) had typical marine $\delta^{13} \mathrm{C}$ values ( -0.8 to $+0.8 \%$ ), suggesting other possible reasons for the increased MRE, such as carbonates derived from limestone depleted in ${ }^{14} \mathrm{C}$. 
Including the previously studied pre-bomb samples from the Adriatic, the MRE for algae is calculated as $378 \pm 44{ }^{14} \mathrm{C}$ yr and $\Delta \mathrm{R}$ as $28 \pm 45{ }^{14} \mathrm{C}$ yr, which correspond to the previously published values for the Adriatic area. When the results for the sampled mussel shells $\left(513 \pm 53{ }^{14} \mathrm{C} \mathrm{yr}\right)$, which had a substantially larger MRE, are added, the resulting MRE increases to $424 \pm 57{ }^{14} \mathrm{C}$ yr and $\Delta \mathrm{R}$ to $77 \pm$ $57{ }^{14} \mathrm{C}$ yr, which is similar to the general MRE previously obtained for the Mediterranean (396 \pm 61 ${ }^{14} \mathrm{C}$ yr). Thus, it is necessary to be aware of the mussel shells' high MRE, regardless of their $\delta^{13} \mathrm{C}$ values, when using them in paleoenvironmental studies or sea-level research. The quantification of ${ }^{14} \mathrm{C}$ reservoir offsets is essential for achieving better accuracy, particularly when comparing marine and continental geochronological records for the entire Mediterranean, as the geomorphological, geological, climatological, and archaeological data are closely related.

\section{ACKNOWLEDGMENTS}

This study was supported by the Croatian Science Foundation, project no. 1623 (Reconstruction of the Quaternary environment in Croatia using isotope methods) and by the University of Zagreb Support for 2013 no. 4.1.1.28 (Research on the influence of palaeo and recent climate changes on processes in marine and continental environments).

Our gratitude goes to the Natural History Museums in Rijeka and Zagreb, the National Museum in Zadar, and to the Natural History Museum and Zoo in Split who provided samples of pre-bomb marine organisms. We are particularly grateful to Milvana Arko-Pijevac, Vesna Štamol, Snježana Vujčić-Karlo, and Nediljko Ževrnja for assisting with the selection of the most suitable samples from the museum collections. We would also like to thank Kita Macario and Ines Krajcar Bronić for fruitful discussions, as well as Ivica Rendulić for assistance with the figures. Our gratitude also goes to the guest editor Alexander Dreves and to the two reviewers (Nadine Tisnérat-Laborde and one anonymous) for the very useful comments that helped us to improve the manuscript.

\section{REFERENCES}

Antonioli F, Anzidei M, Lambeck K, Auriemma R, Gaddi D, Furlani S, Orru P, Solinas E, Gaspari A, Karinja S, Kovačić V, Surace L. 2007. Sea-level change during the Holocene in Sardinia and in the northeastern Adriatic (central Mediterranean Sea) from archaeological and geomorphological data. Quaternary Science Reviews 26(19-21):2463-86.

Antonioli F, Faivre S, Ferranti L, Monaco C. 2011. Tectonic contribution to relative sea level change. Quaternary International 232(1-2):1-4.

Ascough P, Cook G, Dugmore A. 2005a. Methodologi$\mathrm{cal}$ approaches to determining the marine radiocarbon reservoir effect. Progress in Physical Geography 29(4):532-41.

Ascough P, Cook G, Dugmore A, Scott EM, Stewart PH, Freeman T. 2005b. Influence of mollusk species on marine $\Delta R$ determinations. Radiocarbon 47(3):43340.

Ascough P, Cook G, Dugmore A. 2009. North Atlantic marine ${ }^{14} \mathrm{C}$ reservoir effects: implications for late-Holocene chronological studies. Quaternary Geochronology 4(3):171-80.

Benac Č, Juračić M, Bakran-Petricioli T. 2004. Submerged tidal notches in the Rijeka Bay NE Adriatic Sea: indicators of relative sea-level change and of recent tectonic movements. Marine Geology 212(14):21-33.
Bevington PR. 1969. Data Reduction and Error Analysis for the Physical Sciences. New York: McGraw-Hill.

Boaretto E, Mienis HK, Sivan D. 2010. Reservoir age based on pre-bomb shells from the intertidal zone along the coast of Israel. Nuclear Instruments and Methods in Physics Research B 268(7-8):966-8.

Bronk Ramsey C. 2009a. Bayesian analysis of radiocarbon dates. Radiocarbon 51(1):337-60.

Bronk Ramsey C. 2009b. Dealing with outliers and offsets in radiocarbon dating. Radiocarbon 51(3):1023-45.

Bronk Ramsey C, Lee S. 2013. Recent and planned developments of the program OxCal. Radiocarbon 55(2-3):720-30.

Cherkinsky AE, Culp RA, Dvoracek DK, Noakes JE. 2010. Status of the AMS facility at the Center for Applied Isotope Studies, University of Georgia. Nuclear Instruments and Methods in Physics Research B 268 (7-8):867-70.

Costello MJ, Bouchet P, Boxshall G, Arvantidis C, Appeltans W. 2008. European register of marine species. URL: http://www.marbef.org/data/erms.php. Accessed 26 January 2015.

Facorellis Y, Vardala-Theodoru E. 2015. Sea surface radiocarbon reservoir age in the Aegean Sea from about 11,200 BP to present. Radiocarbon 57(3):491-503. 
Faivre S, Fouache E. 2003. Some tectonic influences on the Croatian shoreline evolution in the last 2000 years. Zeitschrift für Geomorphologie 47(4):52137.

Faivre S, Bakran-Petricioli T, Horvatinčić N. 2010. Relative sea-level change during the Late Holocene on the Island of Vis (Croatia) - Issa Harbour archaeological site. Geodinamica Acta 23(5-6):209-23.

Faivre S, Fouache E, Ghilardi M, Antonioli F, Furlani S, Kovačić V. 2011. Relative sea level change in Istria (Croatia) during the last millennia. Quaternary International 232(1-2):132-43.

Faivre S, Bakran-Petricioli T, Horvatinčić N, Sironić A. 2013. Distinct phases of relative sea level changes in the central Adriatic during the last 1500 years influence of climatic variations? Palaeogeography, Palaeoclimatology, Palaeoecology 369:163-74.

Florido E, Auriemma R, Faivre S, Radić Rossi I, Antonioli F, Furlani S, Spada G. 2011. Istrian and Dalmatian fishtanks as sea level markers. Quaternary International 232(1-2):105-13.

Fouache E, Faivre S, Dufaure J-J, Kovačić V, Tassaux F. 2000. New observations on the evolution of the Croatian shoreline between Poreč and Zadar over the past 2000 years. Zeitschrift für Geomorphologie 122:33-46.

Fouache E, Faivre S, Dufaure J-J, Ghilardi M, Kovačić V, Carre M-B, Tassaux F. 2011. 5000 d'évolution relative du niveau marin en Istrie: qu'en est-il à l'époque romaine? In: Carre M-B, Kovačić V, Tassaux F, editors. L'Istrie et la mer. La côte du Parentin dans l'Antiquité. Bordeaux: Ausonius-Mémoires. p 69-88.

Furlani S, Cucchi F, Biolchi S, Odorico R. 2011. Notches in the northern Adriatic Sea: genesis and development. Quaternary International 232(1-2):158-68.

Gačić M, Poulain P-M, Zore-Armanda M, Barale V. 2001. Overview. In: Cushman-Roisin B, Gačić M, Poulain P-M, Artegiani A, editors. Physical Oceanography of the Adriatic Sea. Norwell: Kluwer Academic. p 1-44.

Gillikin DP, Lorrain A, Bouillon S, Willenz P, Dehairs F. 2006. Stable carbon isotope composition of Mytilus edulis shells: relation to metabolism, salinity, $\delta^{13} \mathrm{C}_{\mathrm{DIC}}$, an phytoplankton. Organic Geochemistry 37(10): 1371-82.

Gillikin DP, Lorrain A, Meng L, Dehairs F. 2007. A large metabolic carbon contribution to the $\delta^{13} \mathrm{C}$ record in marine aragonitic bivalve shells. Geochimica et Cosmochimica Acta 71(12):2936-46.

Guiry MD, Guiry GM. 2015. AlgaeBase. World-wide electronic publication, National University of Ireland, Galway. http://www.algaebase.org. Accessed 26 January 2015

Kanduč T, Medaković D, Dolenec T. 2006. Isotopic characteristics of shells Mytilus galloprovincialis from eastern coastal area of Adriatic Sea. Geologija 49(1):133-40. In Slovenian.

Krajcar Bronić I, Horvatinčić N, Sironić A, Obelić B, Barešić J, Felja I. 2010. A new graphite preparation line for AMS ${ }^{14} \mathrm{C}$ dating in the Zagreb Radiocarbon Laboratory. Nuclear Instruments and Methods in Physics Research B 268(7-8):943-6.

Laborel J, Morhange C, Lafont R, Le Campion J, Laborel-Deguen F, Sartoretto S. 1994. Biological evidence of sea-level rise during the last 4500 years on the rocky coasts of continental southwestern France and Corsica. Marine Geology 120(3-4):20323.

Langone L, Asioli A, Correggiari A, Trincardi F. 1996. Age-depth modelling through the late Quaternary deposits of the central Adriatic basin. Memorie Istituto Italiano Idrobiologica 55:177-96.

Lee D, Carpenter SJ. 2001. Isotopic disequilibrium in marine calcareous algae. Chemical Geology 172(34):307-29.

Macario KD, Souza RCCL, Aguilera OA, Carvalho C, Oliviera FM, Alves EQ, Chanca IS, Silva EP, Douka $\mathrm{K}$, Decco J, Trindade DC, Marques AN, Pamplona FC. 2015. Marine reservoir effect on the southeastern coast of Brazil: results from the Tarioba shellmound paired samples. Journal of Environmental Radioactivity 143:14-9.

Mangerud J, Bondevik S, Gulliksenc S, Hufthammerd AK, Høisætere T. 2006. Marine ${ }^{14} \mathrm{C}$ reservoir ages for 19th century whales and molluscs from the North Atlantic. Quaternary Science Reviews 25(2324):3228-45.

Marriner N, Morhange C, Faivre S, Flaux C, Vacchi M, Miko S, Boetto G, Radic Rossi I. 2014. Post-Roman sea-level changes on Pag Island (Adriatic Sea): dating Croatia's "enigmatic" coastal notch? Geomorphology 221:83-94.

Morhange C. 1994. La mobilité récente des littoraux provençaux (The recent mobility of the Provencal littoral) $[\mathrm{PhD}$ thesis]. Géographie Physique, Université de Provence, Centre d'Aix, Faculté des Lettres et des Sciences Humaines, Institut de Geography.

Orlic M, Gacic M, La Violette PE. 1992. The currents and circulation of the Adriatic Sea. Oceanologica Acta 15(2):109-24.

Petricioli D, Bakran-Petricioli T, Kodba Z, Jalžić B. 1995. Basic biological characteristics of vruljas in Modrič and Zečica coves (eastern coast of the Adriatic Sea, Croatia). In: Tvrtković N, editor. Paklenički zbornik - Proceedings of the Symposium on the Occasion of 45th Anniversary of the National Park Paklenica (Starigrad-Paklenica, October 1994) Volume 1. Starigrad: National Park Paklenica. p 195-8.

Pikelj K, Juračić M. 2013. Eastern Adriatic coast (EAC): geomorphology and coastal vulnerability of a karstic coast. Journal of Coastal Research 29(4):944-57.

Reimer PJ, McCormac FG. 2002. Marine radiocarbon reservoir corrections for the Mediterranean and Aegean seas. Radiocarbon 44(1):159-66.

Reimer PJ, Bard E, Bayliss A, Beck JW, Blackwell PG, Bronk Ramsey C, Buck CE, Cheng H, Edwards RL, Friedrich M, Grootes PM, Guilderson TP, Haflidason H, Hajdas I, Hatté C, Heaton TJ, Hoffmann DL, Hogg AG, Hughen KA, Kaiser KF, Kromer B, Man- 
ning SW, Niu M, Reimer RW, Richards DA, Scott EM, Southon JR, Staff RA, Turney CSM, van der Plicht J. 2013. IntCal13 and Marine13 radiocarbon age calibration curves 0-50,000 years cal BP. Radiocarbon 55(4):1869-87.

Russell N, Cook GT, Ascough PL, Scott EM, Dugmore AJ. 2011. Examining the inherent variability in $\Delta R$ : new methods of presenting $\Delta \mathrm{R}$ values and implications for MRE studies. Radiocarbon 53(2):277-88.

Siani G, Paterne M, Arnold M, Bard E, Metivier B, Tisnérat N, Bassinot F. 2000. Radiocarbon reservoir ages in the Mediterranean Sea and Black Sea. Radiocarbon 42(2):271-80.

Sironić A, Krajcar Bronić I, Horvatinčić N, Barešić J, Obelić B, Felja I. 2013. Status report on the Zagreb Radiocarbon Laboratory - AMS and LSC results of VIRI intercomparison samples. Nuclear Instruments and Methods in Physics Research B 294:185-8.

Stuiver M, Braziunas TF. 1993. Modeling atmospheric ${ }^{14} \mathrm{C}$ influences and radiocarbon ages of marine samples back to 10,000 BC. Radiocarbon 35(1):137-89.

Stuiver M, Polach HA. 1977. Discussion: reporting of ${ }^{14} \mathrm{C}$ data. Radiocarbon 19(3):355-63.
Stuiver M, Pearson GW, Braziunas T. 1986. Radiocarbon age calibration of marine samples back to 9000 cal yr BP. Radiocarbon 28(2B):980-1021.

Stuiver M, Reimer P, Reimer R. 2015. Marine reservoir correction database, The 14CHRONO Centre, Queen's University Belfast, Belfast. URL: http:// calib.qub.ac.uk/marine/.

Vlahović I, Tišljar J, Velić I, Matičec D. 2005. Evolution of the Adriatic carbonate platform: palaeogeography, main events and depositional dynamics. $P a$ laeogeography, Palaeoclimatology, Palaeoecology 220(3-4):333-60

Vrsalović D. 1979. Underwater archaeological investigations in the eastern Adriatic (Arheološka istraživanja u podmorju istočnog Jadrana) [PhD thesis]. Zagreb: University of Zagreb.

Ward GK, Wilson SR. 1978. Procedures for comparing and combining radiocarbon age determinations: a critique. Archaeometry 20(1):19-31.

Wheeler A. 1992. Mechanisms of molluscan shell formation. In: Bonnucci E, editor. Calcification in Biological Systems. Boca Raton: CRC Press. p 179-216. 